\title{
NORMATIVE AND PRACTICAL CHALLENGES OF THE REPUBLIC OF MACEDONIA IN THE APPLICATION OF THE RIGHT TO A FAIR TRIAL PRINCIPLE
}

DOI: $10.1515 /$ seeur-2015-0005

\section{INTRODUCTION}

The first forms of communal living were characterized by unwritten rules of behaviour; by the time, however, and creation of organized forms of social structure, specific rules of behaviour were established, and at that phase their creation and implementation were entrusted to the sovereign i.e. to the state as a public reaction against so far private reaction to criminality.

At the very beginning, such rules of behaviour ensured the survival of those communities, and elementary values of the community were subject to protection. The decisions not always contain therein the second segment i.e. the individual protection against authority later defined as guaranteeproving function of criminal law, in particular its protection in the course of finding guilty, this in condition of inexistence of adequate judicial procedural instruments to guarantee unnecessary breach of the individual freedom and this will interim constitute restriction of the sovereign power and eventual misuse in the proceedings.

Throughout civilization development criminal justice system or the state (sovereign) has manifested different approach to this need. Following the first forms of collective reaction in the primordial community in which revenge dominated, the occurrence of a state and public punishment, the sanction was not imposed in the name of the whole group but by and on behalf of clan oligarchy (Kambovski, 2007, p.30), whereby the first forms of punishment were characterized by their severity as expressed in the "Principle of Lex Talionis", "Code of Hammurabi" and "The Law of the Twelve Tables". That dynamics continued in the period of feudalism when authoritarian law was promoted expressed through the Church authority and instrumentalization of absolute ruler's power through establishment of inquisition procedure and exertion of force (torture), as means of plea of guilty (Kambovski, 2007, p.32). "Constitutio Criminalis Carolina" by the emperor Charles V and "Constitutio Criminalis Theresiana" of 1768 featured the same brutality(Kambovski, 2007, p.33).

First major restriction came from Magna Carta (the Great Charter, June 1215), when the monarch restricted his power, and ordinary people acquired certain rights, which influenced the development of ideas for freedom and democracy; an act which would later become foundation of numerous national and international legal acts and documents such as the United States Declaration of Independence (1776), La Declaration des droits de L'Homme et du citoyen (French Revolution, 1789), the United 
Nation Universal Declaration of Human Rights (1948), the European Convention on Human Rights (Council of Europe, 1950) and other relevant legal acts.

All those documents that somehow contain the fundamental commitments included in Magna Carta, ensure appropriate legal balance between the protection of state interest on the one hand, and human rights and freedoms on the other hand as fundamental values of today's democratic legal systems; whereby the level of protection or exercise of human rights is major indicator of the relations between an authority and an individual, i.e. expedient instrument for power restriction (Saiti, 2013, p.9).

\section{SOME IMPORTANT MAGNA CARTA PRINCIPLES AND LATER DOCUMENTS CONTAINING THOSE COMMITMENTS AS THEIR PRINCIPLE POSTULATES.}

Magna Carta in addition to the issues related to sovereignty, family relations, obligations and taxes refers to the composition and manner of courts functioning (in Chapters 18 and 19), promoting the principles of proportionality and formality (in Chapter 20). Not are of minor importance the established restrictions of misuse of office holders related to citizens' material goods provided for in Chapters 28 30. Whereas Chapters 38, 39 and 40 include noticeable procedural guarantees focused on the protection of human rights. Chapter 38 correlates the eventual responsibility with determined facts, while Chapters 39 and 40 establish the principle of legality (No free man shall be seized or imprisoned, or stripped of his rights or possessions, except by the lawful judgment of his equals), the right to a fair trial and the right to trial within reasonable time (To no one will we deny or delay the right or justice).

Fundamental principles of the United States Declaration of Independence (1776) are based (grounded) on natural rights of individuals, i.e., all men are equal, endowed by their Creator with certain unalienable rights, among which are life and freedom. Those rights are secured by a government composed of people who draw their legal power from those they rule over, whereby the principle of accountability of the government is affirmed against the people and its changeability by the people themselves.

"La Declaration des droits de L'Homme et du citoyen" 1789 (Adopted on 26 August, 1789 by the General Estates, this Declaration is one of the essential documents of the French Revolution determining individual and collective rights of the people against the state) is grounded on the same principles as the US Declaration. Fundamental values are recognizable already in Article 1 of the Declaration (Men are born and remain free and equal in rights. Social distinctions can be founded on the common utility), and the following Articles focus on the other values such as freedom (Liberty consists of doing anything which does not harm others) emphasizing the fact that adequate legal guarantees apply to those rights (Article 4). From the aspect of relevance of this study, Articles 7, 8 and 9 are of special importance establishing the principle of legality and presumption of innocence, which clearly defines those provisions.

United Nations Universal Declaration of Human Rights (UN, 1948) guarantees the right to freedom and equality (Article 1, All human beings are born free and equal in dignity and rights), the right to life and the right to security (Article 3). It prohibits torture, inhuman or degrading treatment or punishment. It provides for equality before the law without any discrimination (Article 3), secures the principle of legality, rule of law and presumption of innocence (Article 7).

The Charter of Fundamental Rights of the European Union (2000/C364/01, Nice 7 December 2001) at the very beginning pursues inviolability of human dignity, the right to life, prohibition of torture and degrading treatment and punishment. This document particularly emphasizes the right to effective remedy and fair trial (Article 47 paragraph 1, The right to an effective remedy before a tribunal in compliance with the conditions laid down in this Article. Paragraph 2, Everyone is entitled to a fair and public hearing within a reasonable time by an independent and impartial tribunal previously established by law. Everyone shall have the possibility of being advised, defended and represented), presumption 
of innocence, the right of defence as well as the principle of legality and proportionality of criminal offences and penalties.

The European Convention on Human Rights (Council of Europe,1950) also stresses the right to life, prohibition of torture and forced labour, the right to freedom and security, the right to fair trial, presumption of innocence, the right of defence, the principle of legality and the right to appeal (Articles $2,3,4,5,6,7,13$ and 14$)$.

In the context of the Convention the following principles of the European Court of Human Rights are to be mentioned: the principle of proportionality (Hecker, 2010, p.13); prohibition of discrimination; principle of determination; "Lex mitior" principle and particular forms of the principle "ne bis in idem", as general principles of the Community law (Hecker, 2010, p.1).

Such determinations are envisaged in numerous national legislations of the EU Member States. For instance, the German Code of Criminal Procedure (CCP as of 01.02.1877) includes the most important principles laid down in the ECHR in a form of criminal procedural guarantees such as the principle of formality, accusatory, principle of legality and certainly the principle of immediacy (CCP, xxi), particularly emphasizing the right to fair trial and presumption of innocence (Articles 3 and 6).

The above factography clearly and unambiguously manifests the validity of the fundamental determinations of Magna Carta throughout the civilization development in the acts of the most important international organizations and their documents.

Magna Carta and all other later documents grounded on those principles, have indisputably reflected the legal system of the Republic of Macedonia.

\section{NORMATIVE AND PRACTICAL CHALLENGES OF THE REPUBLIC OF MACEDONIA IN THE APPLICATION OF THE PRINCIPLE OF FAIR TRIAL NATIONAL LEGAL MECHANISMS AND PRACTICES APPLICATION OF THE CONVENTION OF HUMAN RIGHTS AND THE PRACTICE OF THE EUROPEAN COURT OF HUMAN RIGHTS.}

\subsection{NORMATIVE PRESUMPTIONS OF THE REPUBLIC OF MACEDONIA ENSURING THE RIGHT TO FAIR TRIAL}

The Constitution of the Republic of Macedonia as the supreme act contains basic postulates guaranteeing the fundamental human and citizen freedoms and rights of fair trial (Article 8 of Constitution of RM). The first group of guaranteed rights are the following: right to equality, right to life, prohibition of torture and degrading behaviour, right to freedom, presumption of innocence, principle of restitution, right to effective remedy and principle of legality.

The Constitution of the Republic of Macedonia also includes appropriate legal mechanisms ensuring rule of law, defining judicial authority as autonomous and independent authority. Courts administer justice on the basis of the Constitution, laws, and international agreements ratified in accordance with the Constitution.

This implies that our Constitution refers to application of the Convention for the Protection of Human Rights and Fundamental Freedoms (Article 98 and 119 of Constitution of RM 'Sources of Law; Supreme Court of RM, Collection of Court Decisions 2004-2014, Book XI, Legal opinion No 4, p. 36), permanently taking into consideration the principle of subsidiary when applying conventional law as a corrective law of legal systems and national courts i.e. of the authorities of signatory countries 
interfering in situations only when national courts may not secure effective protection of the rights guaranteed by the Convention (Saiti, 2014).

The above obligation is also provided for in the Law on Courts (Article 2(1)), Code on Criminal Procedure (Article 3 ) and in the provisions of other procedural laws.

The most important mechanisms for protection of human rights provided for in the Convention are embedded in the basic principles of the Code on Criminal Procedure as follows: presumption of innocence, principle of legality and proportionality, the right to fair trial, the right to trial within reasonable time, prohibition of double proceedings and etc. (Articles 1-8 of the CCP).

The new Code on Criminal Procedure, which introduced a new type of criminal procedure (accusatory procedure) is characterized by emphasized role of the procedural fairness and principle of contradiction in main hearing (Калајџиев \& Лажетик-Бужаровска, 2011, p. 11). This Code recognizes the basic principles and commitments of the Great Charter and the other significant acts above, whereby the criminal codes of USA, Italy and Germany have the most influence, without excluding the influence of the English Criminal Code when speaking about the Law on Determining and Imposing Penalties and the efforts relating to introduction of Probation System and Probation Service.

From the aspect of this study, of special importance is the right to fair trial ensured by Article 5 of the Code on Criminal Procedure (A person convicted of crime has a right to fair and public trial before an independent and impartial tribunal. In a contradictory procedure he/she may oppose the accusations and propose and present evidence). The text of this Article makes reference to clear rights and obligations of the procedural factors which fully originate from and are harmonized with the obligations arising from the legally relevant acts such as the European Convention on Human Rights as continuation of Magna Carta and generally accepted determinations in the other acts and documents.

Not less important are the provisions of Article 6 - right to trial within reasonable time and Article 2 presumption of innocence, which along with the provisions guaranteeing minimum rights comprise the corpus of normative guarantees ensuring the right to fair trial, and for that purpose it is very important to secure the right to fair trial at all stages of criminal proceedings, as from the investigation itself (Калајџиев \& Лажетиќ-Бужаровска, 2011, p. 24).

Article 70 of the CCP (2010) provides for the fundamental rights of the defendant (Sufficient time and possibilities to prepare their own investigation, and in particular to have insight into the file and to be acquainted with the evidence against him/her or in his/her favor as well as to communicate with a defense attorney of his/her choice; to be judged in the presence of his attorney and to defend personally or by an attorney; to present his/her defense; to have possibility to state the facts and evidence.), and in this context, the provisions referred to detention are very important, as from the grounds for determining the detention (165), the authority in charge of determining detention in previous proceedings (166), and in particular, the provisions referred to in Article 168 laying down the obligation related to bringing the detained person before a judge and defining a defence attorney, whereby in the course of a previous procedure the judge will hear both parties as well as the defence attorney about the circumstances of importance for determining the detention, and to established the necessity of determining the detention, which during the investigation procedure may extend to 90 days, while for offences for which at least 4-year imprisonment may be imposed, the detention may be prolonged for 90 days after the public prosecutor have elaborated the proposal (CCP, 2010, Article 171).

The above provisions are not accidently given in this study. In our judicial practice, in appellate procedure, the defence attorney not rarely recalls to violation of the right of defence and inequality of arms in terms of lack of delivery of detention as a measure imposed by the public prosecutor to the adverse party so that they may address those allegations (Acting upon an appeal related to these circumstances, the Supreme Court of RM, in certain situations has taken actions for "convalidation" of such violations made by courts deciding in first instance. See, Vkz 1. No 5/2015). 
For the right of defence and equitable remedies related to the proceeding stages (investigation), of special importance are the provisions referred to in Articles 293-318 of the CCP (2010) related to participation of the suspect, defence attorney and the indemnified party in the investigation procedure and their rights.

Chapter XXIV of the CCP (2010) governs the main hearing and the right of the parties in the proceedings, while the following Chapter provides for provisions related to a verdict, determining at the beginning which evidence may be (CCP, 2010, Article 339) or may not be grounds of the verdict (Article 340, A sentence may not ground only on the basis of the testimony provided by an indemnified witness under the provisions related to concealing their identities or appearance for the purpose of their protection and protection of their close persons and only on the grounds of the testimony produced in accordance with Article 388 paragraphs 2 and 3 of this Law).

The next Chapter governs appellate procedures, as of the appellate grounds (Article 414) further to essential violations of the criminal procedure provisions emphasizing violation of the right of defence (Article 415(3)).

With regard to the right of defence, CCP (2010) provides for appropriate guarantees even in the institute "Repeating the proceedings in favour of the convicted" (Article 449), which in addition to other legal opportunities, paragraph 6 provides for the possibility of repeating the proceedings in case where a valid decision of the European Court of Human Rights has established any violations of the human rights and fundamental freedoms during the proceedings (Kvp.KOK1.Kvp. No 5/2014, Case of Trampevski vs $\mathrm{RM})$.

The right to fair trial is subject to revision by the Supreme Court and through the institutes "Request for protection of legality" and "Request for extraordinary revision of a valid verdict". Despite the fact that the grounds for submitting a request for extraordinary revision are stricter, they are exactly focused on violations related to the right to a fair trial, expressed through violation of the provisions related to criminal proceedings as provided for in Article 415(1) points 1, 5, 8,9 and 10, and in particular due to violation of the right of defence (Equivalent to Article 6 of the European Convention - provisions of which are embedded in our $\mathrm{CCP}$ ) or violation of the provisions related to criminal proceedings in appellate procedure.

Those guarantees secured by the right to fair trial or the principle of fair trial were also included in the previous Criminal Procedure Code $(1997,2005)$ as of the basic principles all through the specific chapters and articles governing particular issues.

Article 4 guarantees the right to fair trial by way of guaranteeing the minimum rights equivalent to the rights provided for in any important acts, among which the Convention of Human Rights. This Code also governs the presumption of innocence, prohibition of torture or force of confession, principles of restitution and rehabilitation as well as other legally binding universal principles (CCP, (1997)2005, Articles 2, 10, 11).

Of particular importance is that the CCP ensures procedural guarantees in all stages of proceedings as of the investigation itself (CCP, (1997) 2005, Article 171).

Provisions governing appellate procedure ensure significant procedural guarantees, which assist the parties or the convicted to deny eventual procedural actions manifesting violation of the proceedings or the right to fair trial (Article 381 - Essential violations of the criminal procedure provisions, and in particular paragraph 2 of this Article that governs the right of defense).

However, despite this fact, such designed legal system in the Republic of Macedonia faces numerous challenges in the administration of justice. Taking into consideration so far structure of the judicial 
system of the Republic of Macedonia encompassed by the European Court of Human Rights and its practice, the judicial system has manifested certain weaknesses which are not rarely repeated.

How does the Republic of Macedonia deal with this problem?

Taking into account the fact that in our national procedural law does not originate from the law as well as the limited authorizations of the Supreme Court in unification of judicial practice, this Court, however, making use of its Constitutional position as a highest court and ensuring uniform application of laws by the courts, it provides special contribution to securing the right to fair trial both through its decisions and through its principle positions and legal opinions.

Although principle positions and legal opinions are not binding for the councils of lower courts, their legal argumentation increasingly applies in the lower courts decisions as follows:

First, as valid and reasonable legal reasoning and argumentation, and

Second, as an approach to ensure quality decisions, acceptable for the highest court.

The Supreme Court of the Republic of Macedonia permanently finds the strength of its arguments in the national legislation as well as in the international acts and legal documents, in particular in the European Convention on Human Rights and the European Court of Human Rights decisions.

In that context some cases of the Supreme Court will be presented further in the study, decisions focused on securing the right to fair trial as practical challenges facing the judiciary of the Republic of Macedonia.

\subsection{PRACTICAL CHALLENGES IN SECURING THE RIGHT TO FAIR TRIAL.}

\section{CASE NO 1}

\section{Violation of the Right to Defence or Violation of the Right to Fair Trial - Kzz No 32/2014}

Deciding on the Request for Protection of Legality Initiated by the Public Prosecutor's Office of the Republic of Macedonia against the verdicts of the Basic Court Tetovo and Appellate Court Gostivar, the Supreme Court of the Republic of Macedonia has established that:

- Article 366(1) point 6 of the CCP has been violated as the judgment was adopted by a court which due to its subject-matter jurisdiction might not administer that case due to a reason that the convicted were found guilty and sentenced for a crime "Trafficking in persons" pursuant to Article 418a(1) of the Criminal Code which, in compliance with Article 32(1) indent 4 of the Law on Courts, is in jurisdiction of the Basic Court Skopje 1 Skopje, or precisely, the specialized court unit for trial of crimes in the area of organized crime and corruption (Verdict Kzz No 32/2014 as of 12.11.2014).

- The Request for protection of legality effectively indicates to violation of Article 355(1) point 8 and Article 355(2) of the CCP.

The Court has found that sentences of lower courts are grounded on the indemnified party's testimony (Face-to-face confrontation between the defendant and the indemnified in the hearing) provided in the minutes in the emergency hearing without presence of the defendant's attorney, while the defence was mandatory. 
In this way the Court also violated Article 355(2) of the CCP since they have violated the right to defence of the accused in the main hearing. Such violation interim constitutes violation of the right to fair trial guaranteed by Article 6 of the ECHR.

In its explanatory note to this decision, the Supreme Court of the Republic of Macedonia made reference to the European Court practice (case - Trampevski vs RM) and established that: "This right requires that the defence is given adequate opportunity to hear the witness either in the moment of the testimony or in further phase of the proceedings (In a cited decision it is indicated that the right of defense is limited within the scope inadequate with the requirements provided for in Article 6, if the verdict is grounded exclusively on or overriding the witness's testimonies, who, the accused did not have possibility to question either in the course of the investigation or in the course of the trial - see the case of Trampevski vs RM).

Consequently, in situation where decisive facts related to the criminal liability of the convicted was mainly established on the basis of the indemnified party's testimony, this Court found that the right to defence and the right to fair trial were violated when the indemnified party was heard at the face-toface confrontation with the accused in the absence of their attorneys, in particular that the defence was mandatory due to the penalty for the envisaged crime.

\section{CASE NO 2}

Violation of the right to fair trial - Kvp.KOK1.Kpv.No 5/2014

Deciding on the Request for Extraordinary Revision of Valid Judgment, the Supreme Court of the Republic of Macedonia has found that the convicted request was well-founded and it was accepted.

Previously the European Court of Human Rights in the case of Trampevski vs RM (Appeal No 4570/07 as of 10.07.2012), made a decision that Article 6 points 1 and 3-d of the European Convention for the Protection of Human Rights and Fundamental Freedoms, the principle of contradiction in the proceedings and fair trial as well as the right of defence of the convicted are violated. In the repeated proceedings the accused was found guilty for the crime "Migrants Smuggling" pursuant to Article 418$\mathrm{b}$ paragraph 2 and imposed a prison sentence.

In his appeal before the Supreme Court of the Republic of Macedonia, the appellant makes reference to essential violations of the criminal procedure provisions as referred to in Article 381(1) point 8 of the $\mathrm{CCP}$, since the effective sentence is grounded on inadmissible evidence related to the migrants' testimonies provided in the investigation procedure, and who are not heard in the main hearing before the court of first instance in presence of the convicted. In that way the provisions referred to in the ECHR and the verdict in the case of the European Court Trampevski vs RM are not observed. This gave no possibility to the accused to face and question the witnesses, so that the principle of contradiction in the proceedings, right of defence in the main hearing and principle of fair trial were violated.

In the repeated proceedings, the court of first instance explained that from the insight into the summons the witnesses were duly notified on the main hearing but they did not appear, and in accordance with the principle of appropriateness and efficiency of the procedure, and observing the terms of reasonable trial, they imposed the sentence without hearing the witnesses in the main hearing.

According to the Supreme Court this conclusion is not sufficient and does not ensure that the violation of the right to fair trial, equality of arms and contradictory in a procedure are convalidated.

The Supreme Court established that Article 6 points 1 and 3-d of the European Convention was violated even in the repeated proceedings, which was also indicated in the decision of the European Court of Human Rights (Trampevski vs RM). 
In this case the convicted and the defence did not have any possibility to question the witnesses in the course of the investigation nor during the repeated trial. The court of first instance attempted but did not make use of all envisaged remedies and instruments to facilitate hearing of the witnesses, face-toface confrontation and to enable cross examination to reassess the truthfulness of their evidence, particularly as it was sole direct evidence against the convicted (Explanatory Note of Verdict Kvp. No 253/2013).

\section{CASE NO 3}

\section{Violation of the right to fair trial - Kvp. No 253/2013}

The court of second instance violated the criminal procedure provisions in an appellate case, the right of defence and Article 6(1) of the European Convention for the Protection of Human Rights and Fundamental Freedoms - the right to fair trial, when at the request by the accused for their summoning he failed to ensure presence of all accused in the public session also attended by the public prosecutor and the attorney of the second and third accused, and he decided in the session that personal presence of the accused is not necessary despite previously sent summons in Macedonian not in Albanian as their native language, which he declared to be used in the course of the proceedings (Supreme Court of R. Macedonia, Collection of Court Decisions 2004-2014, Book XI, Sentence No 90, p. 194).

According to the Supreme Court, such action of the Court violated Article 362(1) and (2) of the CCP, establishing interim that the accused have been duly informed on the public session.

The Court also violated Article 7 of the CCP taking into consideration that in the course of the proceedings the accused used Albanian as their native language, and the summons for the public session had been sent in Macedonian without Albanian translation. Due to the reasons presented in the explanatory note of the judgment, the Supreme Court considers that the criminal procedure provisions were essentially violated resulting to violation of the right of defence as defined in Article 413 point 3 of the CCP.

The Court also assumes that in this manner Article 6(1) of the European Convention on the Protection of Human Rights and Fundamental Freedoms was violated, or precisely, the right to fair trial.

In its explanatory note, the Court makes reference to the judicial practice as follows: "Namely, in compliance with the judicial practice of the European Court of Human Rights, the principle of equality of arms - one of the elements of the wider concept of fair trial requires that each of the parties is given reasonable possibility to present its cause, in such conditions that will not put this party in disadvantage against its opponents.

Further the explanatory note emphasizes the need for securing enjoyment of ECHR guarantees - "At the same time, the country establishing appellate and cassation courts is required to ensure that the persons subject to law will enjoy the guarantees provided for in Article 6 of the European Convention for the Protection of Human Rights and Fundamental Freedoms before those courts" (Kvp. No 253/2013, quoted from the Explanatory Note).

That Court was also in violation related to Verdict Kz. No 109/14 of 24.032014. The court of second instance in its minutes of a public session established that the convicted serving a sentence in KPU "Idrizovo" Skopje was duly summoned, and making reference to Article 38(2) of the CCP (2005) in the repeated decision found that the presence of the accused in the public session was not appropriate for clarifying the issues and therefore no order for his presence in the public session was issued, in order to avoid additional expenses and delay of the procedure (In the verdict of the Supreme Court of RM, Kvp. No 265/2013 as of 27.12.2013, deciding on the same case, it was established that the Appellate Court misacted when acting upon the appeals filed, held public session without presence of the 
convicted, who served imprisonment for crime - Murder as provided for in Article 123(2) point 6 and criminal act as provided for in Article 396(1) of the CC of RM).

The Supreme Court found that Article 6(1) of the Convention was violated, i.e. that in this case also violation of the right to equality of arms is concerned due to failure of the Court to secure presence of the convicted.

\section{CASE NO 4}

\section{Violation of the right of access to court - Kvp. No 179/2013}

By way of failure to deliver the sentence imposed by the court of first instance to the convicted, he was prevented from filing a remedy, thus violating the right of defence - Article 413(3) of the CCP and interim the right of access to court referred to in Article 6(1) of the European Convention for the Protection of Human Rights and Fundamental Freedoms (Supreme Court of R. Macedonia, Collection of Court Decisions 2004-2014, Book XI, Sentence No 95, p. 204).

Acting upon the request for extraordinary revision of the effective sentence, the Supreme Court of the Republic of Macedonia established that the right of defence of the convicted as provided for in Article 413(1) point 3 of the CCP was violated, and interim the right of access to court provided for in Article 6(1) of the European Convention for the Protection of Human Rights and Fundamental Freedoms.

In its explanatory note the Court makes reference to Article 6(1) of the Convention noting that the said provision of the Convention guaranteeing the right to fair trial implicitly protects the right of access to court as grounds for further exercise of the rights belonging to a citizen in court proceedings.

In that context, failure of the court of first instance to deliver the sentence, the convicted was prevented access to the court in terms of his hampering to duly and timely file a regular remedy against that sentence.

\section{CASE NO 5}

Convalidation of violence of the right to fair trial by the Court imposing sentence in first instance procedure against the proposal for extension of a detention measure - Vkz. 1 No 5/2015

Acting upon the appeal filed by the accused attorney, the Supreme Court established that the proposal for extension of the detention measure pursuant to Article 171(3) and in connection with Article 165(1) point 1 , was not delivered to the accused and his attorney, whereby hearing was not held, and in compliance with the practice of the European Court of Human Rights such action means violation of the right to fair trial as in the case of Mitrevski vs R. Macedonia.

The Supreme Court of the Republic of Macedonia convalidated such violation as follows:

* Pursuant to Article 169(5) of the CCP the Court called and held a session before its Council, where the Public Prosecutor of RM and the accused attorney were duly invited; however only the attorney attended the session.

* In the session, the attorney was introduced with the reasons for extension of the detention and the Court gave the attorney possibility to address the reasons and the Public Prosecutor's proposal and to present the defence arguments before the Court.

* Consequently, the accused attorney was able to participate in the procedure before the Court thus ensuring the right to fair trial guaranteed under Article 6 of the European Convention for 
the Protection of Human Rights and Fundamental Freedoms (See, Mitreski vs RM, Application No 11621/09, Nikolova v Bulgaria No 31195/96, paragraph 59, ES).

Despite such proactive approach of the Supreme Court of the Republic of Macedonia and other courts, the number of cases initiated before the European Court related to violation of the right of defence, equality of arms, or violation of the right to fair trial is not insignificant, which indicates to a conclusion that a good legislation requires prudent application (See Stoimenov vs RM - Appeal No 17995/02 as of 05.04.207; Solakov vs RM - Appeal No 46023/99, the citizen appeals to violation of Article 6 paragraphs 1 and 3-d of the Convention, violation of the right to fair trial due to lack of possibility to question the prosecution witnesses, and many other cases).

\section{CONCLUSIONS}

1. Republic of Macedonia possesses appropriate normative presumptions ensuring the right to fair trial embedding the basic principles of Magna Carta, ECHR and other relevant acts.

2. Judicial authority of the Republic of Macedonia manifests relevant approach in its efforts to ensure fair trial, whereby the Supreme Court despite its insufficient legal authorizations, by the strength of arguments imposes its judicial practice to lower courts, and aimed at securing uniform application of laws and the right to fair trial.

3. So far function makes reference to the need for permanent education of judges and other participants in a criminal procedure to ensure rule of law and to reduce the number of cases filed before the European Court of Human Rights.

4. Normative upgrade of our legal system is to continue in the spirit of the basic principles of Magna Carta and European law as well as to ensure relevant application of the European Court practice.

\section{WORKS CITED}

Калајџиев, Г., \& Лажетиќ-Бужаровска, Г. (2011). Закон за кривичната постапка. Скопје: Академик.

Kambovski, V. (2007) Criminal Law - General Part

Saiti, Xh. (2013) Alternative Measures against New Forms of Criminality. Skopje.

Saiti, Xh. (2014) Application of ECHR by Domestic Courts, MANU, Skopje

Hecker (2010) European Criminal Law, presented through the Case "Cowan"

Law on Courts, Article 2(1), Official Gazette of RM No.58/06,62/06,35/08,150/10

Code on Criminal Procedure, Official Gazette of RM No 150/2010

Code on Criminal Procedure, Official Gazette of RM No 15/2005, consolidated text

Supreme Court of R. Macedonia, Collection of Court Decisions 2004-2014, Book XI, Sentence No 90 